\title{
Studies Towards the Total Synthesis of Angelmicin B (Hibarimicin B): Synthesis of a Model D'-CD Arylnaphthoquinone System
}

\author{
Sridhar Narayan and William R. Roush* \\ Department of Chemistry, University of Michigan, Ann Arbor, MI 48109 \\ E-mail Address: roush@umich.edu
}

SUPPORTING INFORMATION

Experimental details and spectroscopic data for compounds 11, 14, 15, 17-19, 21, and 22

(21 pages) 


\section{General}

All reactions were carried out in flame-dried glassware under an atmosphere of dry nitrogen or argon. $4 \AA$ molecular sieves were flame dried under vacuum prior to use. Solvents were purified as follows: $\mathrm{THF}$ and $\mathrm{Et}_{2} \mathrm{O}$ were either distilled from sodium benzophenone ketyl or used as is from a solvent purification system (Anhydrous Engineering). $\mathrm{CH}_{2} \mathrm{Cl}_{2}$ was either distilled from $\mathrm{CaH}_{2}$ or used as is from a solvent purification system. DMF was stored over $4 \AA$ M. S., and used without further purification, unless otherwise mentioned.

${ }^{1} \mathrm{H}$ NMR spectra were measured at 500 or $400 \mathrm{MHz}$ on a Varian I-500 or a Varian XL400 instrument respectively. Chemical shifts are reported relative to residual solvent $(\square 7.26,2.5$ and $4.8 \mathrm{ppm}$ for $\mathrm{CDCl}_{3}$, DMSO and $\mathrm{MeOH}$ respectively). ${ }^{13} \mathrm{C}$ NMR spectra were measured at 125 or $100 \mathrm{MHz}$ on a Varian I-500 or a Varian XL-400 instrument respectively. Chemical shifts are reported relative to the central line of $\mathrm{CDCl}_{3}(\square 77.0 \mathrm{ppm})$. Infrared spectra were recorded using a Perkin Elmer Spectrum 1000 FT-IR. High resolution mass spectra were measured on a VG 70-250-S Micromass Inc. mass spectrometer at the University of Michigan Mass Spectrometry Laboratory. Elemental analyses were performed at the Elemental Analysis Laboratory at the University of Michigan.

Analytical thin layer chromatography (TLC) was performed using Whatman glass plates coated with a $0.25 \mathrm{~mm}$ thickness of silica gel containing PF254 indicator, and compounds were visualized with UV light, potassium iodide - iodine stain, $p$-anisaldehyde stain, ceric ammonium molybdate stain, or phosphomolybdic acid in EtOH. Chromatographic purifications were performed using Kieselgel 60, 230-400 mesh silica gel. All compounds purified by chromatography were sufficiently pure for use in further experiments, unless indicated otherwise.

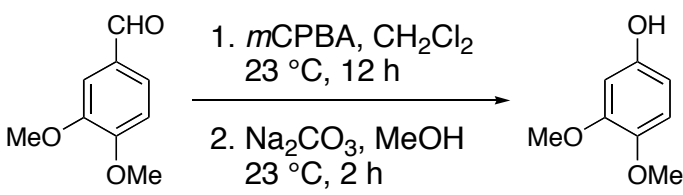

13

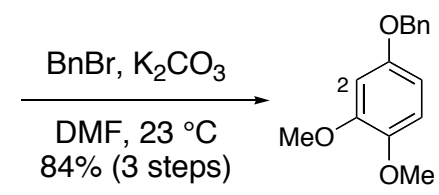

14

\section{1-Benzyloxy-3,4-dimethoxybenzene (14)}

Water-free $m \mathrm{CPBA}^{\#}(6.85 \mathrm{~g}, 39.7 \mathrm{mmol})$ was added in small portions to a solution of

\footnotetext{
\# CAUTION: $m$ CPBA is known to be explosive in its very pure states and therefore should be handled with extreme care. Although we have never encountered any difficulties, removal of the solvent in the following procedure should always be carried out behind a blast shield. A commercial sample of $80-85 \%$ $m$ CPBA $(10 \mathrm{~g})$ was dissolved in $200 \mathrm{~mL}$ of $\mathrm{CH}_{2} \mathrm{Cl}_{2}$, and the water layer separated. The solution was dried over anhydrous sodium sulfate, filtered and concentrated under reduced pressure. This sample of $m \mathrm{CPBA}$ was stored in a $-20^{\circ} \mathrm{C}$ freezer for up to 3 months without deterioration of quality.
} 
veratraldehyde $(5.5 \mathrm{~g}, 33.1 \mathrm{mmol})$ in $30 \mathrm{~mL}$ of $\mathrm{CH}_{2} \mathrm{Cl}_{2}$ and the solution stirred at ambient temperature. Caution: Exothermic reaction. When $m \mathrm{CPBA}$ is added, the reaction flask should be left open. After $30 \mathrm{~min}$, a white precipitate formed and the heterogeneous mixture stopped stirring. Another $30 \mathrm{~mL}$ of $\mathrm{CH}_{2} \mathrm{Cl}_{2}$ was added and the mixture stirred at ambient temperature for $8 \mathrm{~h}$. After this time, the mixture was filtered, and the residue washed with $\mathrm{CH}_{2} \mathrm{Cl}_{2}$. The combined filtrates were washed with sat. $\mathrm{NaHCO}_{3}\left(3 \mathrm{x}\right.$ ), dried (anhydrous $\mathrm{Na}_{2} \mathrm{SO}_{4}$ ) and concentrated to obtain the formate as a yellow oil. This material was directly subjected to the methanolysis conditions.

The crude formate from the previous step was dissolved in $15 \mathrm{~mL}$ of $\mathrm{MeOH}$ and $\mathrm{Na}_{2} \mathrm{CO}_{3}$ $(5.26 \mathrm{~g}, 49.7 \mathrm{mmol})$ added. The dark green solution was stirred at ambient temperature for $2 \mathrm{~h}$, after which time TLC analysis indicated complete consumption of the starting formate. Most of the methanol was removed under reduced pressure and the oily slurry partitioned between water and EtOAc. The layers were separated, and the aqueous layer further extracted with EtOAc (2x). The combined organic extracts were washed with brine, dried $\left(\mathrm{Na}_{2} \mathrm{SO}_{4}\right)$, filtered and concentrated under reduced pressure. The crude phenol was obtained as a reddish brown solid.

To a solution of the phenol in DMF $(15 \mathrm{~mL})$ was added $\mathrm{K}_{2} \mathrm{CO}_{3}(6.87 \mathrm{~g}, 49.7 \mathrm{mmol})$ and benzyl bromide $(5.91 \mathrm{~mL}, 49.7 \mathrm{mmol})$. This mixture was stirred at ambient temperature for 12 h. When TLC indicated completion of the reaction, $100 \mathrm{~mL}$ water was added and the aqueous solution was extracted three times with $\mathrm{Et}_{2} \mathrm{O} \bullet$ hexanes $(8: 2)$. The combined extracts were washed with brine, dried (anhydrous $\mathrm{Na}_{2} \mathrm{SO}_{4}$ ), filtered and concentrated. Purification of the crude material by flash column chromatography (15\% EtOAc in hexanes) afforded a sample of pure 14 $(6.83 \mathrm{~g}, 84 \%)$ as a clear oil. The spectroscopic data for this sample of $\mathbf{1 4}$ matched previously reported data for this compound. ${ }^{1}$

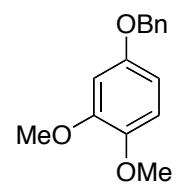

14

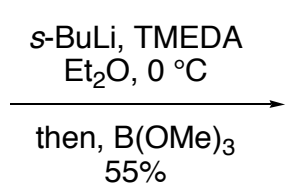

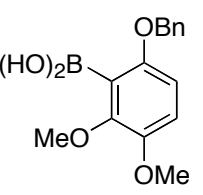

15

\section{(6-Benzyloxy-2,3-dimethoxyphenyl) boronic acid (15)}

$s$-BuLi (3.57 mL of a $1.49 \mathrm{M}$ solution in cyclohexane, $5.32 \mathrm{mmol}$ ) was added dropwise, to a solution of arene $14(520 \mathrm{mg}, 2.13 \mathrm{mmol})$, TMEDA (803 $\square \mathrm{L}, 5.32 \mathrm{mmol})$ in $\mathrm{Et}_{2} \mathrm{O}(8 \mathrm{~mL})$ at $0{ }^{\circ} \mathrm{C}$. The orange red solution was stirred at $0{ }^{\circ} \mathrm{C}$ for $1.75 \mathrm{~h}$, after which trimethyl borate $(1.19$ $\mathrm{mL}, 10.7 \mathrm{mmol}$ ) was added in one portion. The mixture was then allowed to attain ambient temperature. TLC analysis at this time indicated a small amount of starting material present. The reaction mixture was added to a $1 \mathrm{M} \mathrm{HCl}$ solution and the aqueous solution extracted with $\mathrm{Et}_{2} \mathrm{O}$ 
(3x). theombined extracts were dried $\left(\mathrm{Na}_{2} \mathrm{SO}_{4}\right)$ and concentrated. The curde product was purified by flash column chromatography (40\% EtOAc in hexanes) to obtain $\mathbf{1 5}$ as a pale brown solid (337 mg, 55\%). Data for 14: $\mathrm{mp} 117-120{ }^{\circ} \mathrm{C}$; ${ }^{1} \mathrm{H}$ NMR $\left(500 \mathrm{MHz}, \mathrm{CD}_{3} \mathrm{OD}\right) \square 7.27$ - 7.15 (m, $5 \mathrm{H}), 6.76$ and $6.54\left(\mathrm{AB}\right.$ system, $\left.J_{\mathrm{AB}}=8.8 \mathrm{~Hz}, 2 \mathrm{H}\right), 4.86(\mathrm{~s}, 2 \mathrm{H}), 3.67(\mathrm{~s}, 3 \mathrm{H}), 3.64(\mathrm{~s}, 3 \mathrm{H}) ;{ }^{13} \mathrm{C}$ NMR (125 MHz, $\left.\mathrm{CD}_{3} \mathrm{OD}\right) \square 155.6,152.1,147.9,139.0,129.4,128.7,128.6,128.1,115.1,115.0$, 108.2, 108.1, 108.0, 71.4, 60.9, 60.7, 56.7, 56.6; IR (Thin film) $\mathrm{cm}^{-1}$; HRMS (ES) calcd. for $\mathrm{C}_{15} \mathrm{H}_{17} \mathrm{O}_{5}\left(\mathrm{M}+\mathrm{Na}^{+}\right): 311.1067$, found 311.1069 .

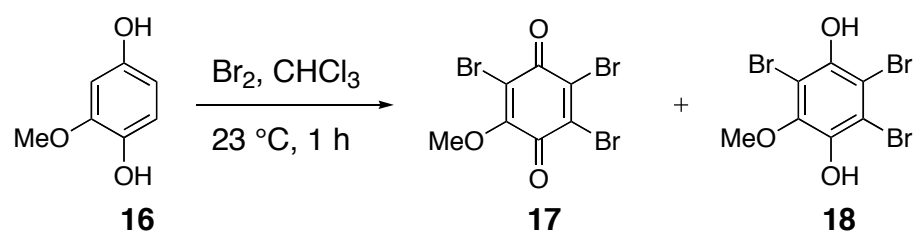

\section{2,3,5-Tribromo-6-methoxy-[1,4]benzoquinone (17)}

Bromine $(5 \mathrm{~mL}, 97.5 \mathrm{mmol})$ was added to a solution of methoxyhydroquinone $(2.8 \mathrm{~g}, 20$ mmol) in $\mathrm{CHCl}_{3}$ and the mixture stirred at ambient temperature for $1 \mathrm{~h}$. At this time TLC analysis indicated the formation of quinone $\mathbf{1 7}$, but also a considerable amount of hydroquinone 18. The volatiles were removed under reduced pressure and the crude residue (red solid) was directly used in the subsequent reaction. An analytical sample was prepared by flash column chromatography (15\% EtOAc in hexanes). Data for 17: ${ }^{1} \mathrm{H}$ NMR $\left(500 \mathrm{MHz}, \mathrm{CDCl}_{3}\right) \square 4.24$ (s, $3 \mathrm{H}) ;{ }^{13} \mathrm{C}$ NMR $\left(125 \mathrm{MHz}, \mathrm{CDCl}_{3}\right) \square 172.0,171.6,156.7,138.5,136.6,117.4,62.2$; IR (Thin film) 1679, 1656, 1601, 1559, 1452, 1414, 1308, 1193, 1139, 1064, 944, 812, 776, 738, 717, 677 $\mathrm{cm}^{-1}$; HRMS (EI) calcd. for $\mathrm{C}_{7} \mathrm{H}_{13} \mathrm{O}_{3} \mathrm{Br}_{3}\left(\mathrm{M}^{+}\right)$: 371.7632, found 371.7639; Anal. calcd for $\mathrm{C}_{7} \mathrm{H}_{13} \mathrm{O}_{3} \mathrm{Br}_{3}$ : C, 22.42\%; $\mathrm{H}, 0.81 \%$, found $\mathrm{C}, 22.85 \%$; $\mathrm{H}, 0.80 \%$.

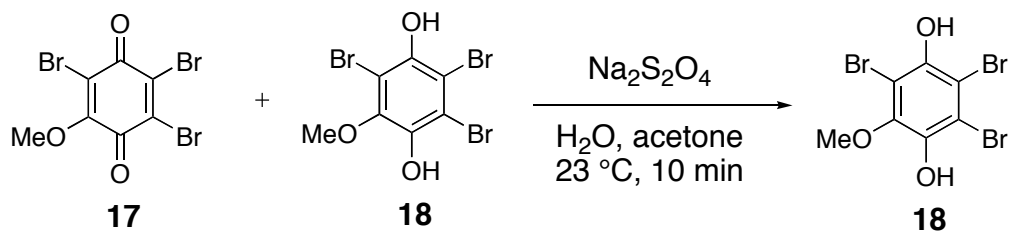

\section{2,3,5-Tribromo-6-methoxy-benzene-1,4-diol (18)}

The mixture of $\mathbf{1 7}$ and $\mathbf{1 8}$ from the bromination reaction was dissolved in acetone (20 $\mathrm{mL})$ and sodium dithionite $(3.48 \mathrm{~g}, 20 \mathrm{mmol})$ in $20 \mathrm{~mL}$ of water was added. The red color of the solution briefly disappeared when a drop of the dithionite solution was added and then reappeared. Ultimately, the red color of the solution gave way to pale yellow, indicating complete consumption of the quinone. The reaction mixture was partitioned between $\mathrm{CH}_{2} \mathrm{Cl}_{2}$ and 
water and the layers separated. The aqueous solution was further extracted with $\mathrm{CH}_{2} \mathrm{Cl}_{2}(2 \mathrm{x})$. The combined extracts were dried $\left(\mathrm{Na}_{2} \mathrm{SO}_{4}\right)$ and concentrated under reduced pressure to obtain the crude product as a yellowish white solid $(6.2 \mathrm{~g})$ that had a strong sulfurous odor. The crude product was directly utilized in the subsequent reaction. Partial data for 18: ${ }^{1} \mathrm{H}$ NMR $(500 \mathrm{MHz}$, $\left.\mathrm{CDCl}_{3}\right) \square 5.50(\mathrm{~s}, 1 \mathrm{H}), 5.31(\mathrm{~s}, 1 \mathrm{H}), 3.89(\mathrm{~s}, 3 \mathrm{H}) ;{ }^{13} \mathrm{C}$ NMR HRMS (EI) calcd. for $\mathrm{C}_{7} \mathrm{H}_{5} \mathrm{O}_{3} \mathrm{Br}_{3}$ $\left(\mathrm{M}^{+}\right)$: 373.7789, found 373.7776; Anal. calcd for: $\mathrm{C}_{7} \mathrm{H}_{5} \mathrm{O}_{3} \mathrm{Br}_{3}: \mathrm{C}, 22.31 \%$; $\mathrm{H}, 1.34 \%$, found $\mathrm{C}$, $22.59 \% ; \mathrm{H}, 1.13 \%$.

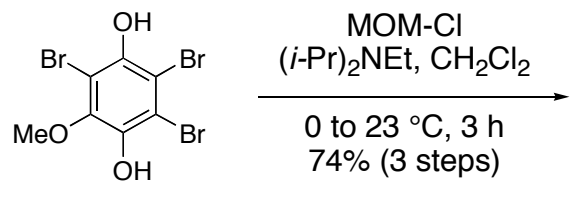

18

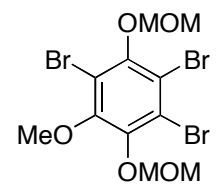

19

\section{1,2,4-Tribromo-5-methoxy-3,6-bis-methoxymethoxybenzene (19)}

To a solution of hydroquinone $18(1.02 \mathrm{~g}, 2.71 \mathrm{mmol})$ in $\mathrm{CH}_{2} \mathrm{Cl}_{2}(5 \mathrm{~mL})$ at $0{ }^{\circ} \mathrm{C}$, was added $\mathrm{MOM}-\mathrm{Cl}(0.514 \mathrm{~mL}, 6.77 \mathrm{mmol})$. After the mixture was stirred at $0{ }^{\circ} \mathrm{C}$ for $2 \mathrm{~min}$, Hünig's base $(1.18 \mathrm{~mL}, 6.77 \mathrm{mmol})$ was added, and the mixture stirred at $0{ }^{\circ} \mathrm{C}$ for $2 \mathrm{~h}$, at which time TLC analysis indicated complete conversion to 19. The reaction mixture was diluted with $\mathrm{CH}_{2} \mathrm{Cl}_{2}(10$ $\mathrm{mL}$ ) and the $\mathrm{CH}_{2} \mathrm{Cl}_{2}$ solution was washed successively with $\mathrm{NH}_{4} \mathrm{Cl}$ solution $(1: 1$, sat. solution + water), water, and sat $\mathrm{NaHCO}_{3}$ solution. The $\mathrm{CH}_{2} \mathrm{Cl}_{2}$ layer was dried $\left(\mathrm{Na}_{2} \mathrm{SO}_{4}\right)$ and concentrated under reduced pressure. Purification of the crude product by flash column chromatography (15\% EtOAc in hexanes) gave 19 as a white solid (1.13 g, 74\% over three steps). Data for 19: $\mathrm{mp}$ 169-170 ${ }^{\circ} \mathrm{C} ;{ }^{1} \mathrm{H}$ NMR (500 MHz, $\left.\mathrm{CDCl}_{3}\right) \square 5.14$ (s, 2H), 5.11 (s, 2H), 3.84 (s, 3H), 3.69 (s, 3H), 3.63 (s, 3H); ${ }^{13} \mathrm{C}$ NMR (125 MHz, $\left.\mathrm{CDCl}_{3}\right) \square 150.9,149.4,146.1,121.0,117.2,114.1,99.6,99.3$, 60.7, 58.5, 58.2; IR (Thin film) 1599, 1469, 1448, 1427, 1382, 1245, 1161, 1098, 1083, 1049, 945, 925, 864, 800, 765, 704, $670 \mathrm{~cm}^{-1}$; HRMS (EI) calcd. for $\mathrm{C}_{11} \mathrm{H}_{13} \mathrm{O}_{5} \mathrm{Br}_{3}\left(\mathrm{M}^{+}\right): 461.8313$, found 461.8324; Anal. calcd for: $\mathrm{C}_{11} \mathrm{H}_{13} \mathrm{O}_{3} \mathrm{Br}_{3}$ : C, 28.42\%; H, 2.82\%, found C, 28.50\%; $\mathrm{H}$, $2.97 \%$. 


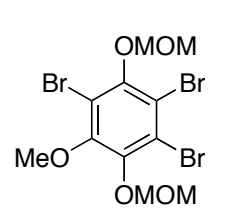

19
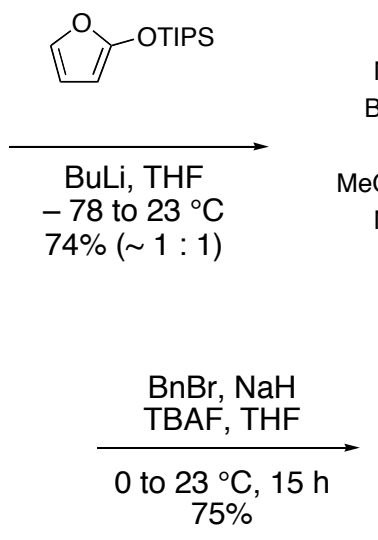

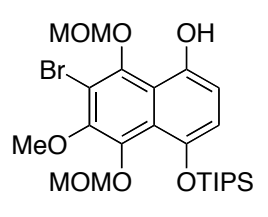

20a

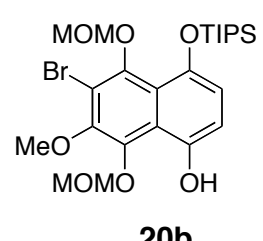

20b

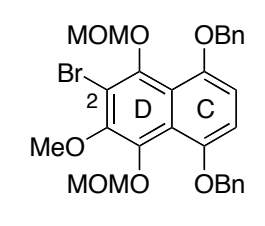

11

\section{5,8-Dibenzyloxy-2-bromo-3-methoxy-1,4-dimethoxymethoxy-naphthalene (11)}

To a solution of dibromide 19 (1.03 g, $2.22 \mathrm{mmol})$ and 2-triisopropylsilyloxyfuran (0.586 $\mathrm{g}, 2.44 \mathrm{mmol})$ in $20 \mathrm{~mL}$ of THF, was added BuLi (1.03 mL of a 2.15 M solution in hexanes, 2.22 mmol) dropwise over 20 min. After being stirred at $-78{ }^{\circ} \mathrm{C}$ for $2 \mathrm{~h}$, the reaction mixture was slowly allowed to attain ambient temperature. Saturated $\mathrm{NH}_{4} \mathrm{Cl}$ and water $(1: 1)$ were added to the reaction mixture and the aqueous solution extracted four times with $\mathrm{Et}_{2} \mathrm{O}$ (containing $\sim 20 \%$ hexanes). The combined $\mathrm{Et}_{2} \mathrm{O}$ extracts were washed with brine, dried $\left(\mathrm{Na}_{2} \mathrm{SO}_{4}\right)$ and concentrated to obtain a red oil. Purification of the crude product by silica gel chromatography (10 to 25\% EtOAc in hexanes) afforded naphthols $\mathbf{2 0 a}, \mathbf{b}(896 \mathrm{mg}, 74 \%)$ in a nearly $1: 1$ regioisomeric ratio. The naphthols $\mathbf{2 0 a}, \mathbf{b}$ readily underwent air oxidation to unidentified quinonoid products. Therefore, they were immediately used in the subsequent step.

$\mathrm{NaH}$ (24 mg, $1.01 \mathrm{mmol}$ ) was added to a solution of naphthols 20a,b (220 mg, 0.403 mmol) and benzyl bromide $(0.24 \mathrm{~mL}, 2.02 \mathrm{mmol})$ in $\mathrm{THF}(5 \mathrm{~mL})$ at $0{ }^{\circ} \mathrm{C}$. The reaction mixture was stirred at $0{ }^{\circ} \mathrm{C}$ for $1 \mathrm{~h}$, then was allowed to attain ambient temperature and stirred for another $4 \mathrm{~h}$. TBAF (1.01 mL of a $1 \mathrm{M}$ solution in THF, $1.01 \mathrm{mmol})$ was then added, and the mixture stirred for $10 \mathrm{~h}$. The reaction mixture was partitioned between sat $\mathrm{NaHCO}_{3}$ and $\mathrm{Et}_{2} \mathrm{O}$, and the layers separated, and the aqueous solution further extracted with $\mathrm{Et}_{2} \mathrm{O}(3 \mathrm{x})$. The combined $\mathrm{Et}_{2} \mathrm{O}$ extracts were washed with brine, dried $\left(\mathrm{MgSO}_{4}\right)$ and concentrated. The crude product was purified by flash column chromatography (15 to 25\% EtOAc in hexanes) to obtain 11 (172 mg, 75\%) as a white solid. Data for 11: $\mathrm{mp} 110-111{ }^{\circ} \mathrm{C} ;{ }^{1} \mathrm{H} \mathrm{NMR}\left(500 \mathrm{MHz}, \mathrm{CDCl}_{3}\right) \square 7.51-7.33$ $(\mathrm{m}, 10 \mathrm{H}), 6.64$ and $6.79\left(\mathrm{AB}\right.$ system, $\left.J_{\mathrm{AB}}=8.5 \mathrm{~Hz}, 2 \mathrm{H}\right), 5.11(\mathrm{~s}, 2 \mathrm{H}), 5.08(\mathrm{~s}, 2 \mathrm{H}), 4.98(\mathrm{~s}, 4 \mathrm{H})$, 3.99 (s, 3H), 3.57 (s, 3H), $3.54(\mathrm{~s}, 3 \mathrm{H}) ;{ }^{13} \mathrm{C} \mathrm{NMR}\left(125 \mathrm{MHz}, \mathrm{CDCl}_{3}\right) \square$ 149.6, 148.8, 148.6, 147.6, 142.7, 136.9, 128.5, 128.0, 127.9, 127.8, 123.1, 120.6, 114.5, 110.4, 110.0, 101.4, 101.0, 72.6, 61.3, 58.3, 57.3, 30.9, 29.7; IR (Thin film) 2921, 2850, 1735, 1664, 1605, 1566, 1497, 1454, 1372, 1345, 1310, 1260, 1212, 1157, 1080, 1023, 961, 931, 797, 736, $697 \mathrm{~cm}^{-1}$; HRMS (ES) calcd. for $\mathrm{C}_{29} \mathrm{H}_{29} \mathrm{BrO}_{7}\left(\mathrm{M}+\mathrm{Na}^{+}\right)$: 591.0994, found 591.1003. 

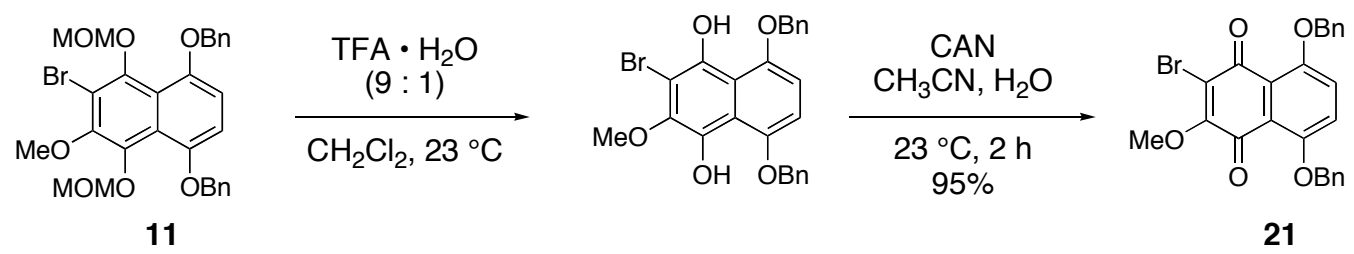

\section{5,8-dibenzyloxy-2-bromo-3-methoxy-[1,4]naphthoquinone (21)}

To a solution of 11 (85 mg, $0.149 \mathrm{mmol})$ in $\mathrm{CH}_{2} \mathrm{Cl}_{2}(3 \mathrm{~mL})$, was added $\mathrm{TFA} \cdot \mathrm{H}_{2} \mathrm{O}(9: 1)$ and the mixture stirred at ambient temperature for $2 \mathrm{~h}$. At this time, reaction mixture was partitioned between $\mathrm{CH}_{2} \mathrm{Cl}_{2}$ and sat $\mathrm{NaHCO}_{3}$ solution. The layers were separated and the aqueous solution further extracted with $\mathrm{CH}_{2} \mathrm{Cl}_{2}(2 \mathrm{x})$. Combined extracts were dried $\left(\mathrm{Na}_{2} \mathrm{SO}_{4}\right)$ and concentrated to obtain the hydroquinone as an orange-yellow solid. Partial data for intermediate hydroquinone: ${ }^{1} \mathrm{H}$ NMR (500 MHz, $\mathrm{CDCl}_{3}$ ) $\square 9.94$ (s, 1H), 9.32 (s, 1H), $7.49-7.40$ (m, 10H), 6.74 and $6.70\left(\mathrm{AB}\right.$ system, $\left.J_{\mathrm{AB}}=8.5 \mathrm{~Hz}, 2 \mathrm{H}\right), 5.20(\mathrm{~s}, 2 \mathrm{H}), 5.19(\mathrm{~s}, 2 \mathrm{H}), 3.92(\mathrm{~s}, 3 \mathrm{H})$.

The crude hydroquinone was dissolved in $\mathrm{CH}_{3} \mathrm{CN}(5 \mathrm{~mL})$ and $\mathrm{CAN}(2 \mathrm{~mL}$ of a $0.1 \mathrm{M}$ solution in $\mathrm{H}_{2} \mathrm{O}, 0.2 \mathrm{mmol}$ ) was added. The mixture was vigorously stirred at ambient temperature for $2 \mathrm{~h}$. At this time, most of the $\mathrm{CH}_{3} \mathrm{CN}$ was removed under reduced pressure, and the residue diluted with water and sat. $\mathrm{NaHCO}_{3}$ solution. The resulting aqueous solution was extracted with $\mathrm{CH}_{2} \mathrm{Cl}_{2}(3 \mathrm{x})$ and the combined extracts dried $\left(\mathrm{Na}_{2} \mathrm{SO}_{4}\right)$ and concentrated. Purification of the crude product by flash column chromatography (25\% EtOAc in hexanes) afforded quinone 21 as a red solid (68 mg, 95\%). Data for 21: mp 138-140 ${ }^{\circ} \mathrm{C}$; ${ }^{1} \mathrm{H}$ NMR (400 $\left.\mathrm{MHz} \mathrm{CDCl}_{3}\right) \square 7.55-7.23(\mathrm{~m}, 12 \mathrm{H}), 5.22$ (s, 2H), 5.19 (s, 2H), 4.23 (s, 3H); ${ }^{13} \mathrm{C}$ NMR $(100$ $\left.\mathrm{MHz}, \mathrm{CDCl}_{3}\right) \square 177.9,177.5,158.8,153.2,136.2,136.1,128.7,128.6,127.9,127.0,126.8$, 123.0, 122.0, 121.0, 120.7, 94.4, 71.8, 71.7, 61.3, 29.7; IR (Thin film): 1672, 1654, 1604, 1584, 1562, 1498, 1477, 1449, 1412, 1381, 1330, 1294, 1268, 1201, 1158, 1100, 1080, 1050, 1030, 1011, 948, 917, 807, 774, 732, 693; HRMS (ES) calcd for $\mathrm{C}_{25} \mathrm{H}_{19} \mathrm{BrO}_{5}\left(\mathrm{M}+\mathrm{Na}^{+}\right)$501.0314, found 501.0313 .

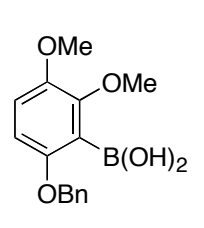

15

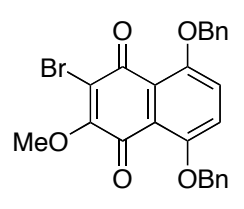

21

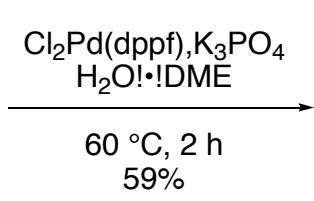

$59 \%$

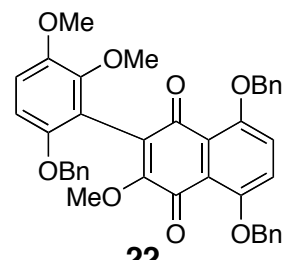

22

\section{5,8-Dibenzyloxy-2-(6-benzyloxy-2,3-dimethoxyphenyl)-3-methoxy-[1,4]naphthoquinone} (22)

Dimethoxyethane (DME) was degassed by sparging argon through it for $15 \mathrm{~min}$. A solution of arylboronic acid 15 (8.4 mg, 29. 2 -mol), bromonaphthoquinone 21 (9.5 mg, 19.8 $\square \mathrm{mol}), \mathrm{Cl}_{2} \mathrm{Pd}(\mathrm{dppf}) \cdot \mathrm{CH}_{2} \mathrm{Cl}_{2}(3.2 \mathrm{mg}, 3.96 \square \mathrm{mol})$ and $\mathrm{K}_{3} \mathrm{PO}_{4}\left(89 \square \mathrm{L}\right.$ of a $1 \mathrm{M}$ solution in $\mathrm{H}_{2} \mathrm{O}, 89$ 
Dmol) in DME $(0.75 \mathrm{~mL})$ was heated at $60{ }^{\circ} \mathrm{C}$ for $2 \mathrm{~h}$. TLC analysis at this point indicated complete consumption of both starting materials. The reaction mixture was cooled to ambient temperature, added to water and extracted with $\mathrm{Et}_{2} \mathrm{O}(4 \mathrm{x})$. The combined extracts were washed with brine, dried $\left(\mathrm{Na}_{2} \mathrm{SO}_{4}\right)$ and concentrated. Purification of the crude product by flash column chromatography (30 to 40\% EtOAc in hexanes) afforded $22(7.5 \mathrm{mg}, 59 \%)$ as a red film. Data for 22: ${ }^{1} \mathrm{H}$ NMR (400 MHz, DMSO) $\square 7.64-7.19(\mathrm{~m}, 17 \mathrm{H}), 7.02$ and $6.78\left(\mathrm{AB}\right.$ system, $J_{\mathrm{AB}}=$ $9.2 \mathrm{~Hz}, 2 \mathrm{H}), 5.29(\mathrm{~s}, 2 \mathrm{H}), 5.20(\mathrm{~s}, 2 \mathrm{H}), 5.02$ and $4.95\left(\mathrm{AB}\right.$ system, $\left.J_{\mathrm{AB}}=12.6 \mathrm{~Hz}, 2 \mathrm{H}\right), 3.79(\mathrm{~s}$, $3 \mathrm{H}), 3.73$ (s, 3H), 3.60 (s, 3H); ${ }^{13} \mathrm{C}$ NMR (125 MHz, DMSO) $\square$ 183.0, 180.0, 157.3, 152.1, 151.7, 150.0, 147.1, 146.7, 137.4, 137.0, 136.9, 128.5, 128.4, 128.3, 127.8, 127.6, 127.5, 127.2, 127.0, 124.2, 123.1, 121.8, 121.0, 120.6, 116.3, 113.2, 107.5, 70.6, 69.8, 60.0, 59.6, 56.0; IR (Thin film) 2923, 2852, 1742, 1661, 1567, 1482, 1453, 1420, 1379, 1274, 1208, 1078, 1028, 964 , 796, 737, 696, 665; HRMS (ES) calcd. for $\mathrm{C}_{40} \mathrm{H}_{34} \mathrm{O}_{8}\left(\mathrm{M}+\mathrm{Na}^{+}\right)$: 665.2151, found 665.2155.

\section{References}

1. Kupchan, S. M.; Liepa, A. J.; Kameswar.V; Sempuku, K. J. Am. Chem. Soc. 1973, 95, 2995. 


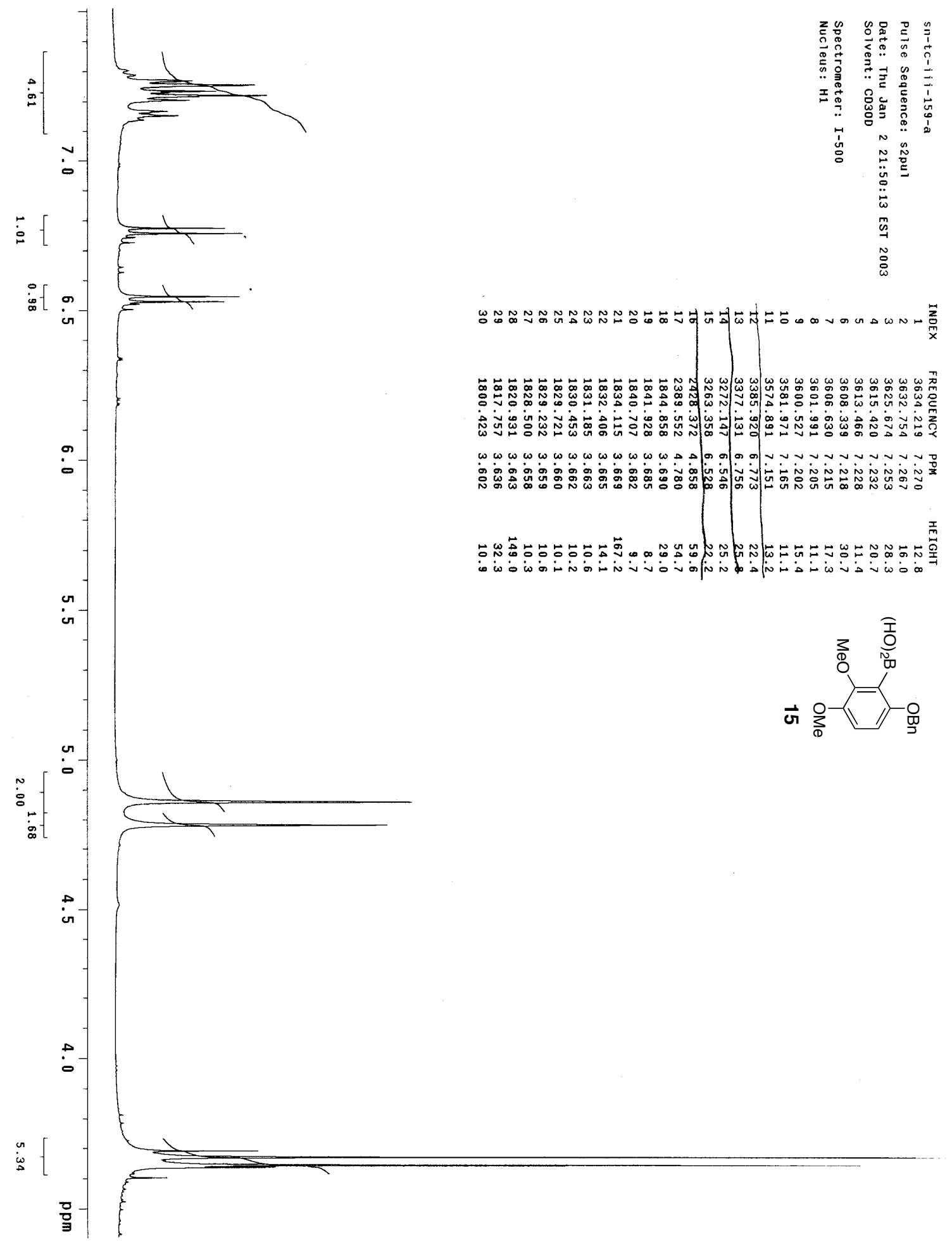




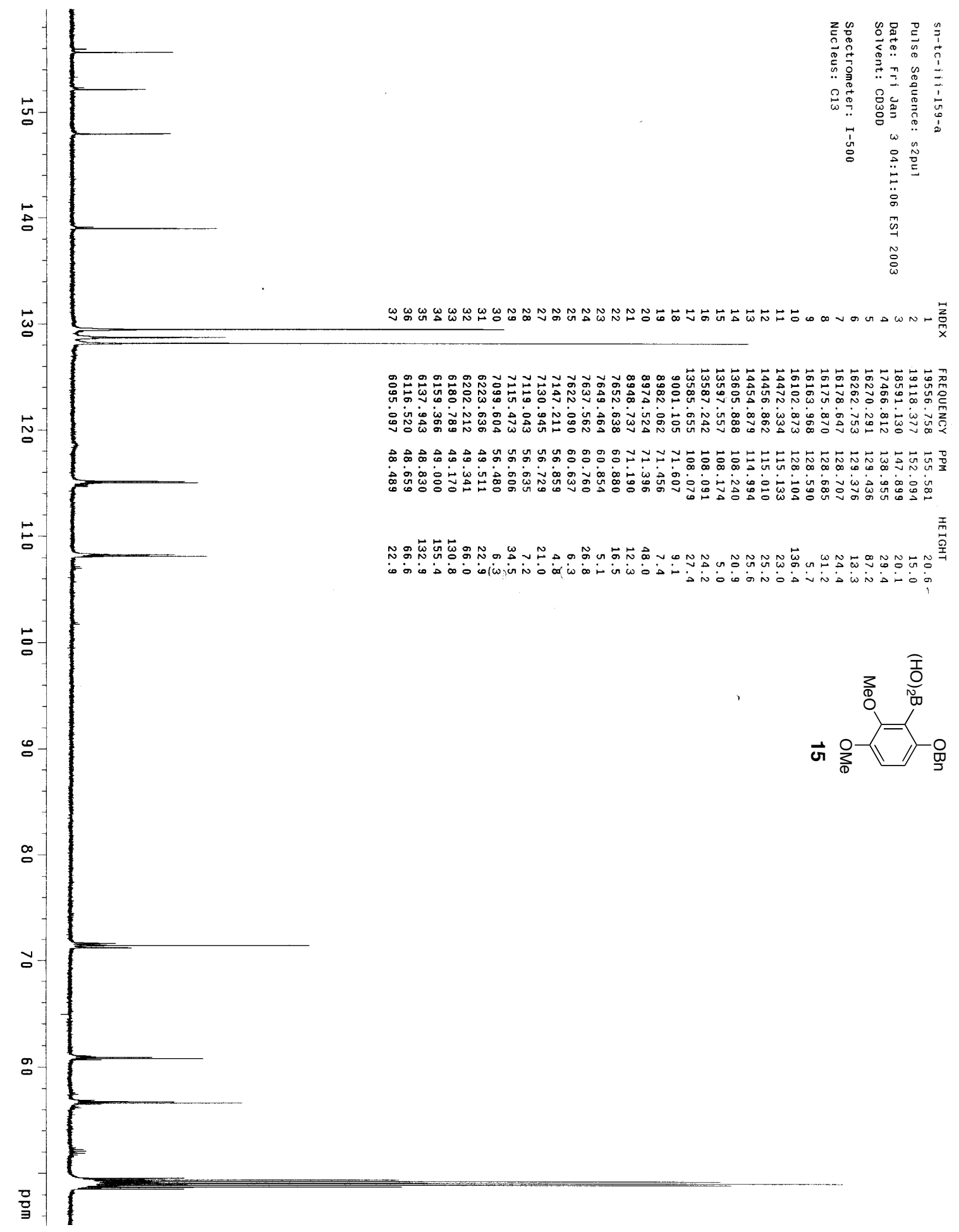




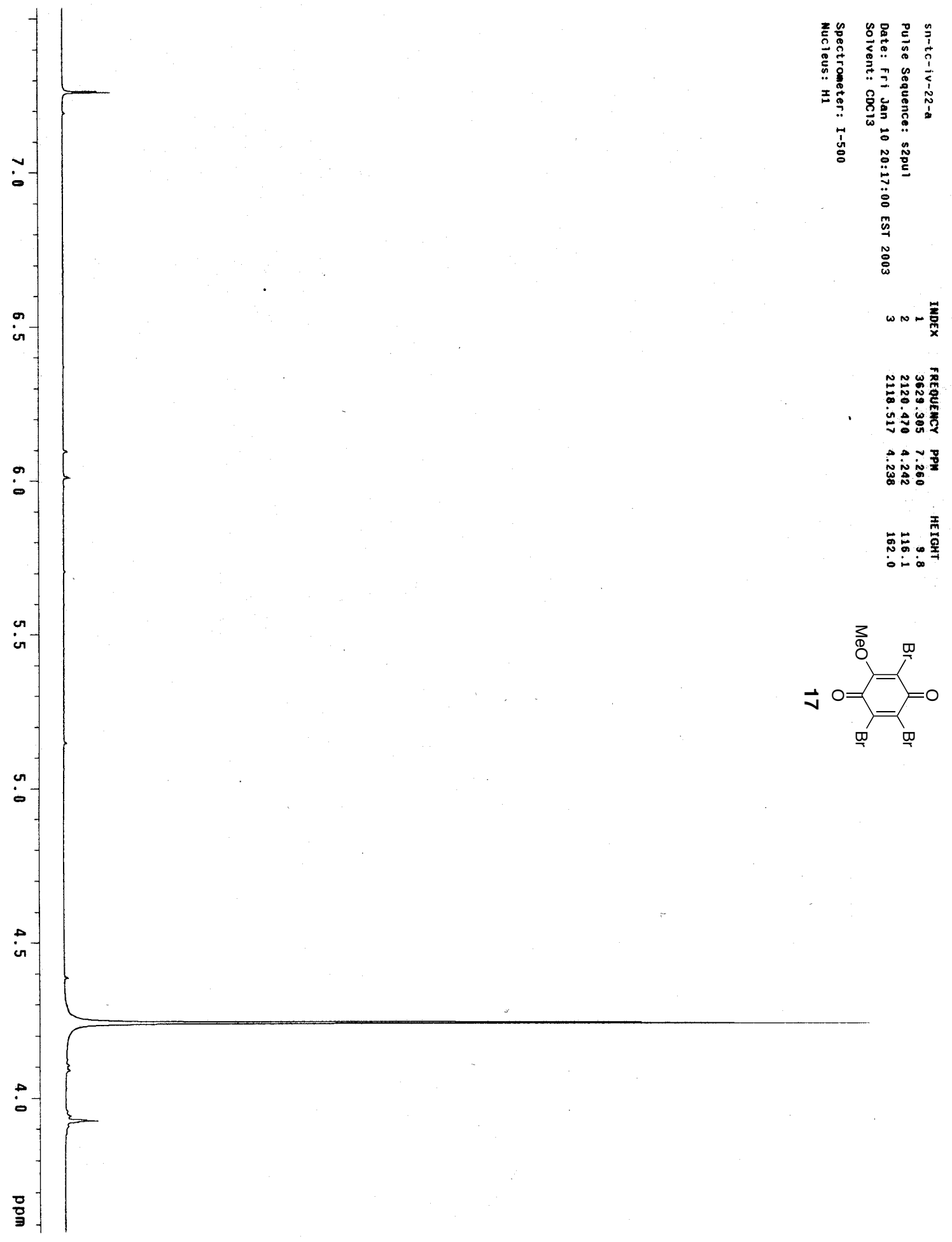



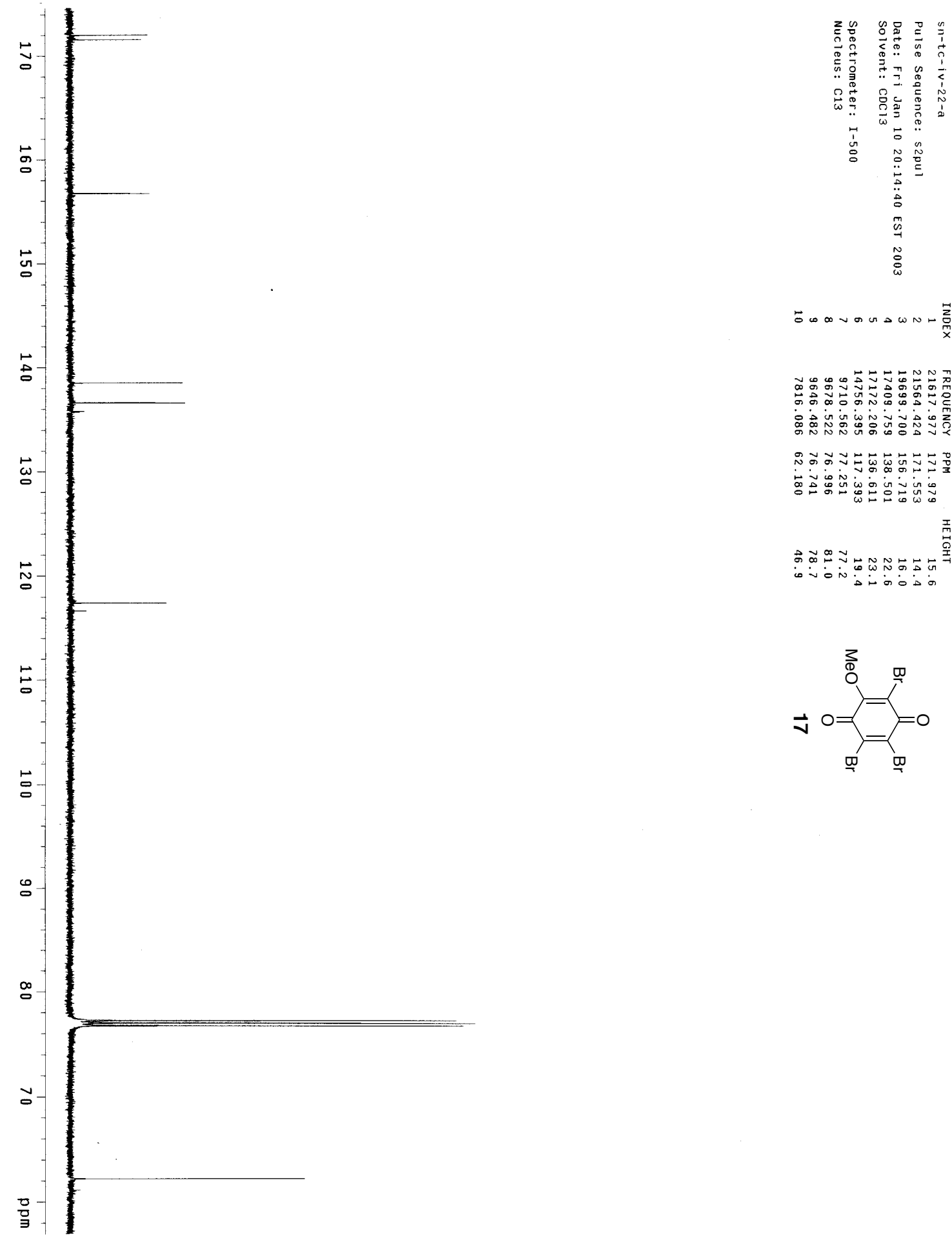

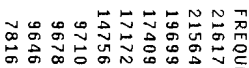

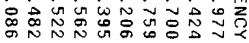

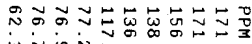

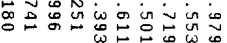

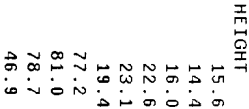

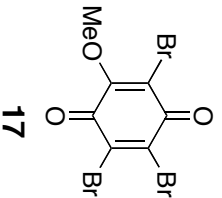




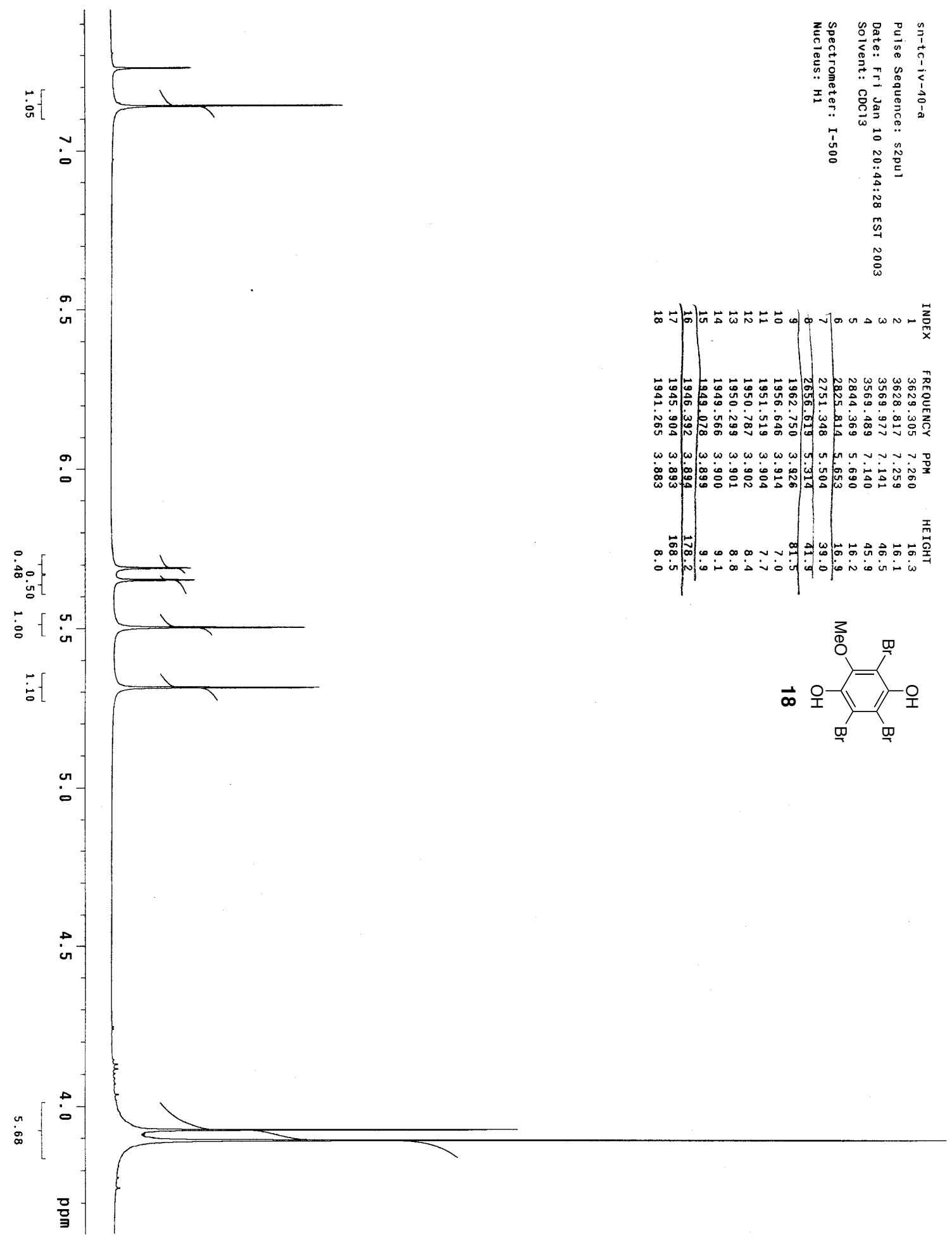




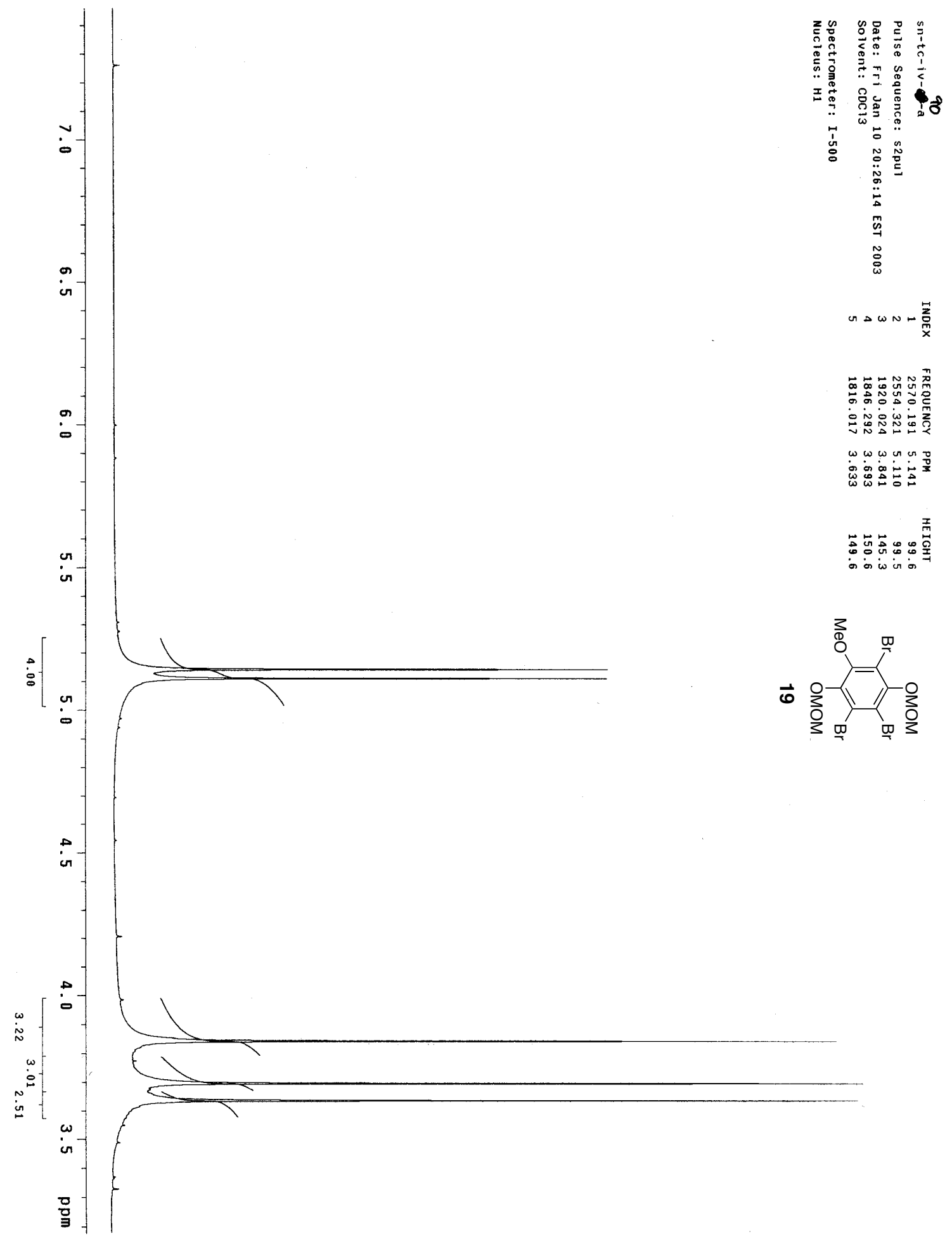




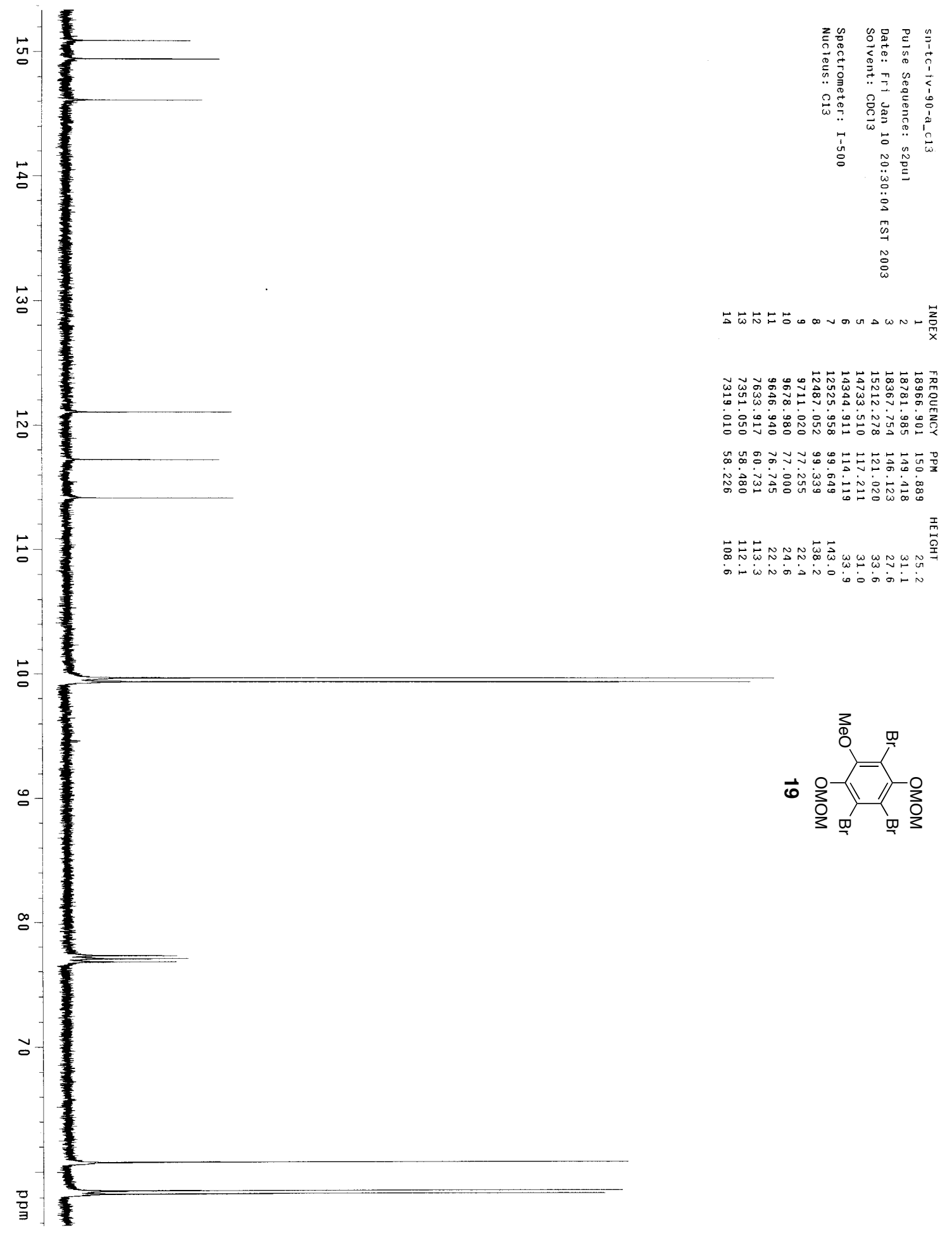




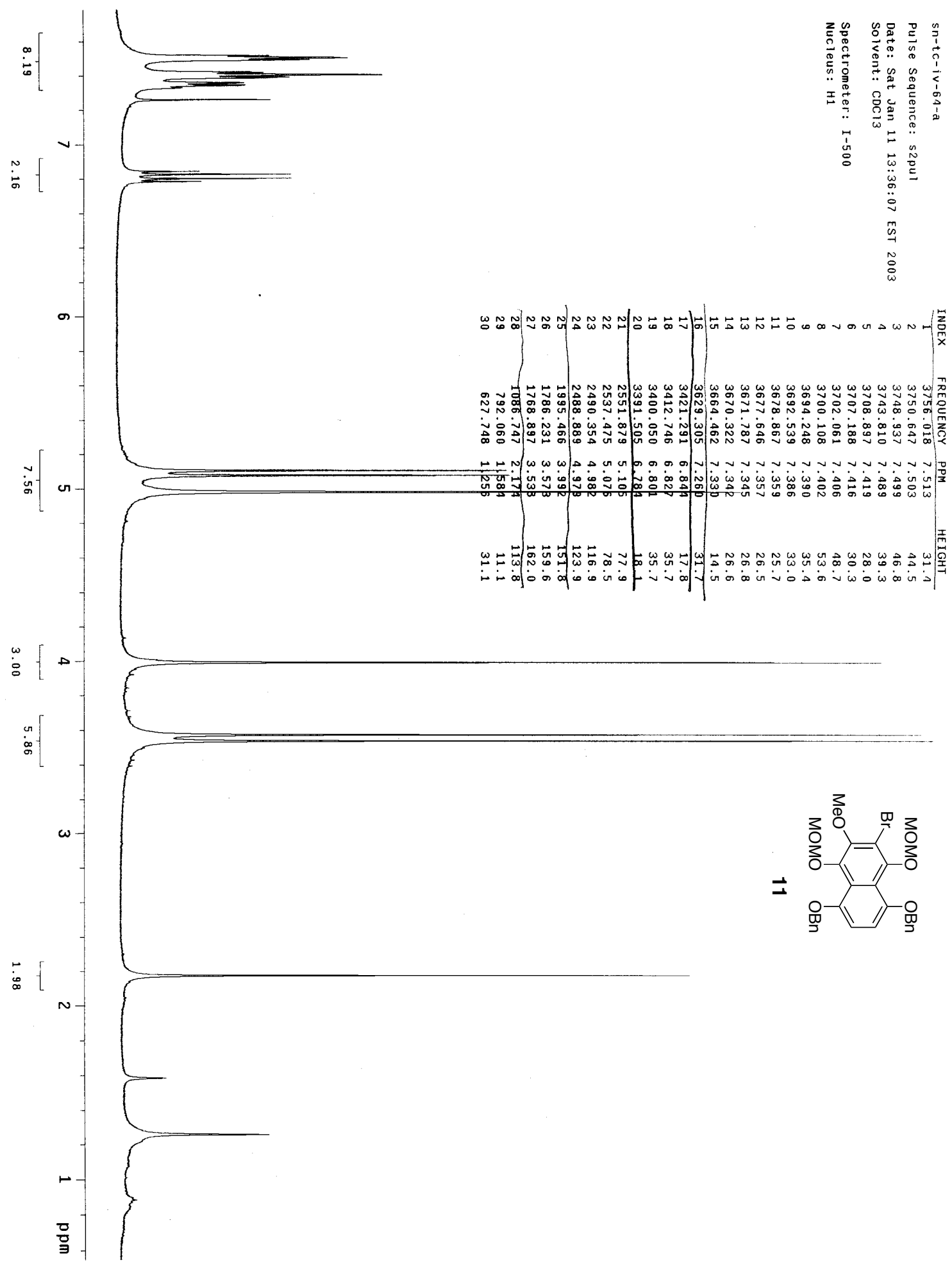




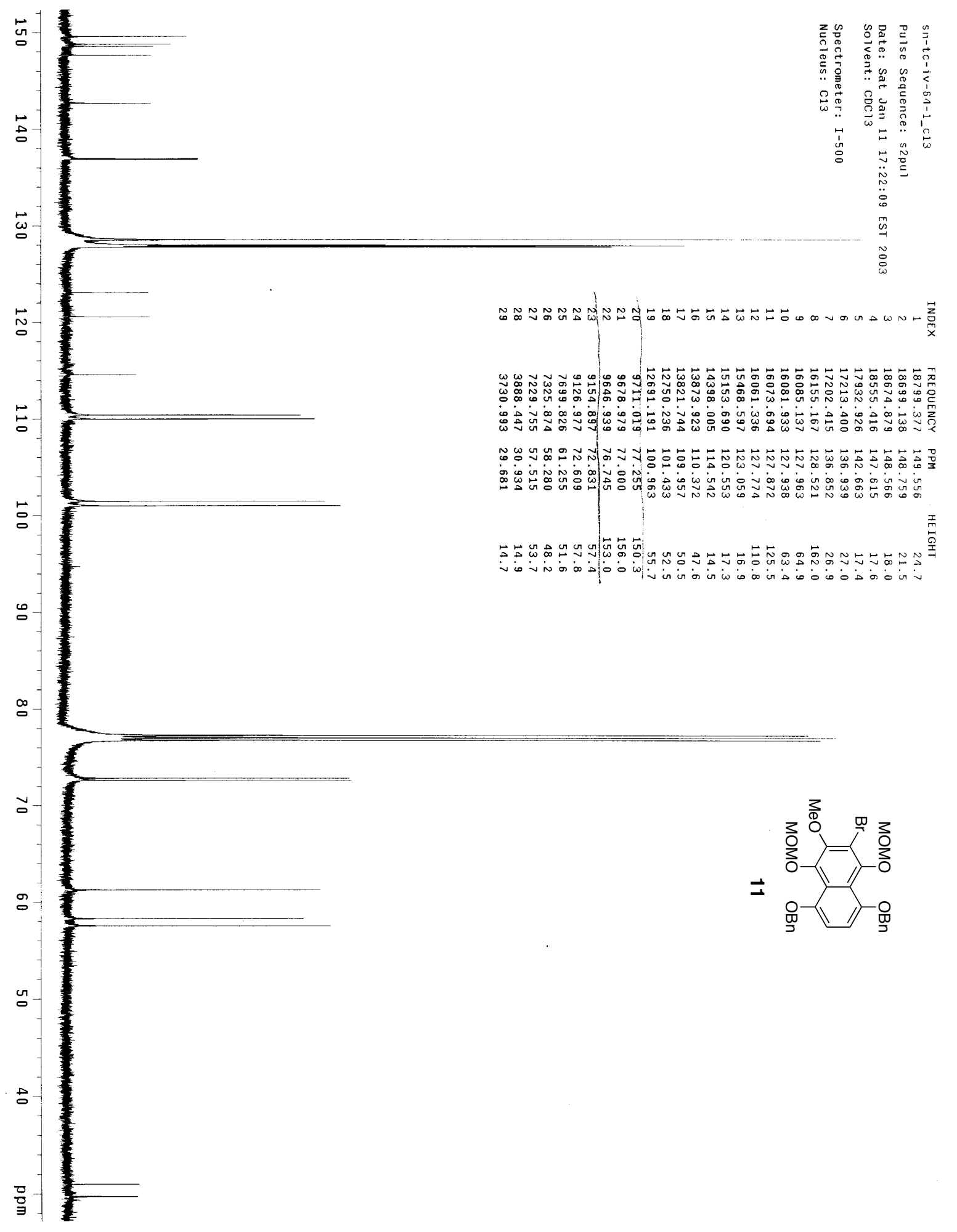




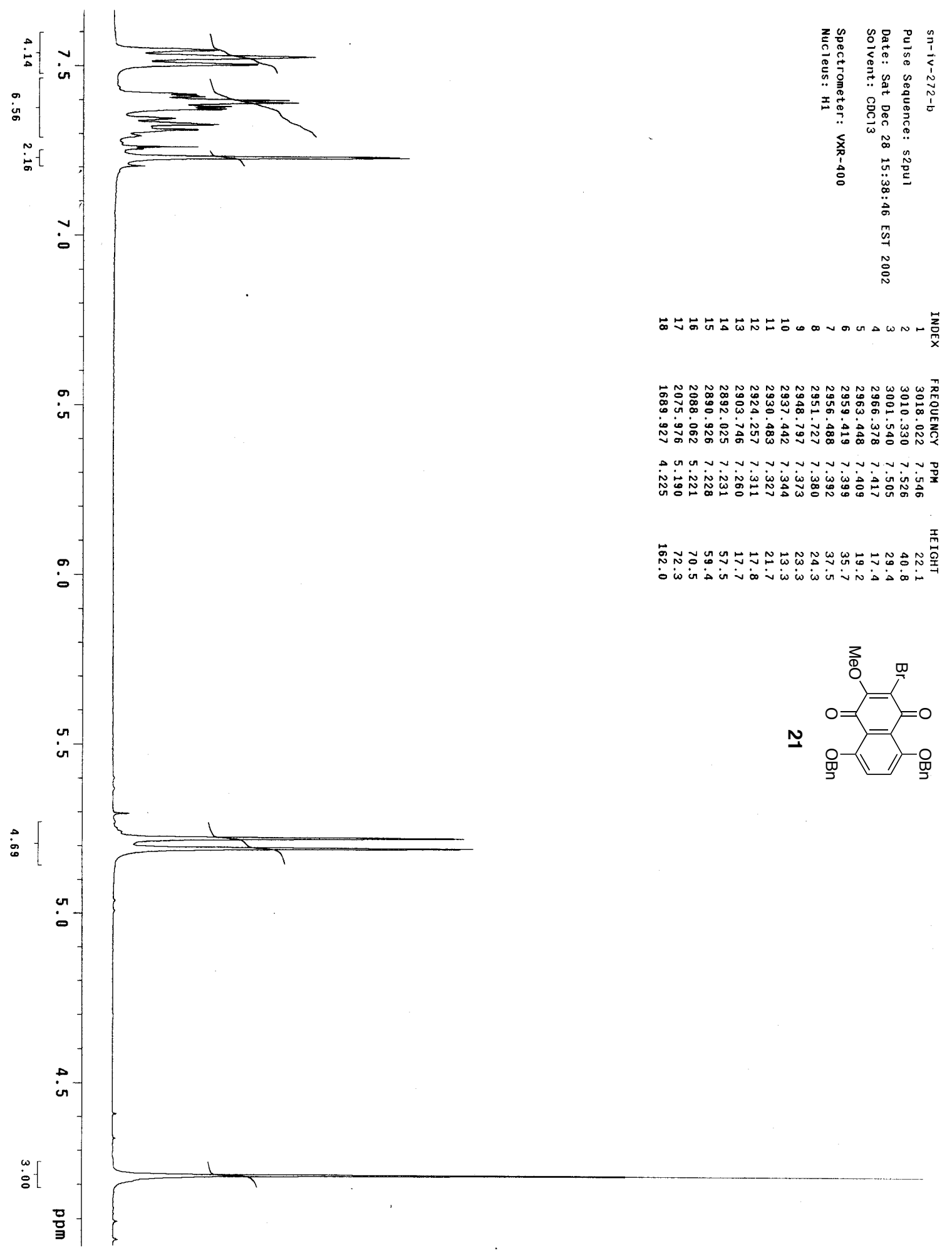




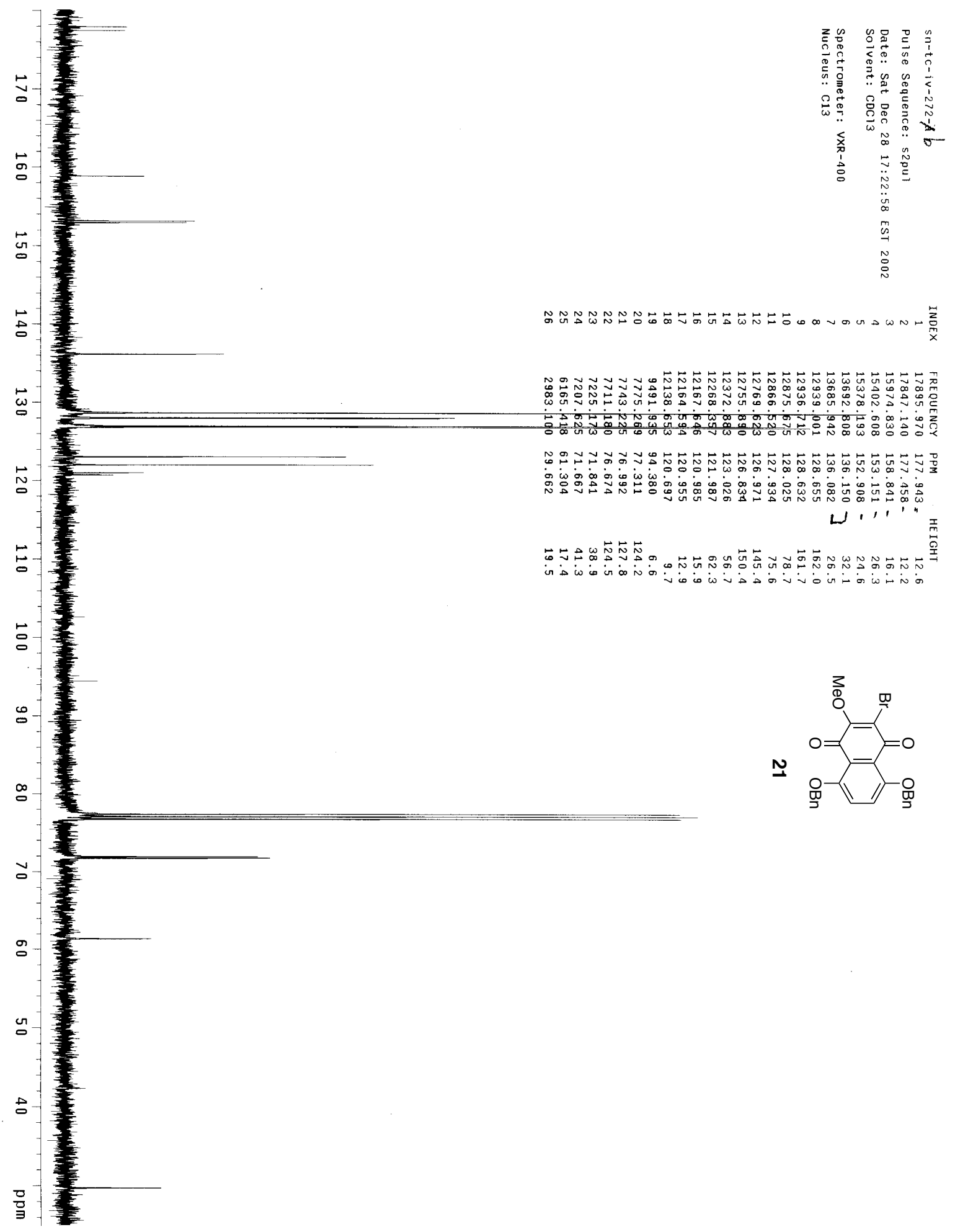




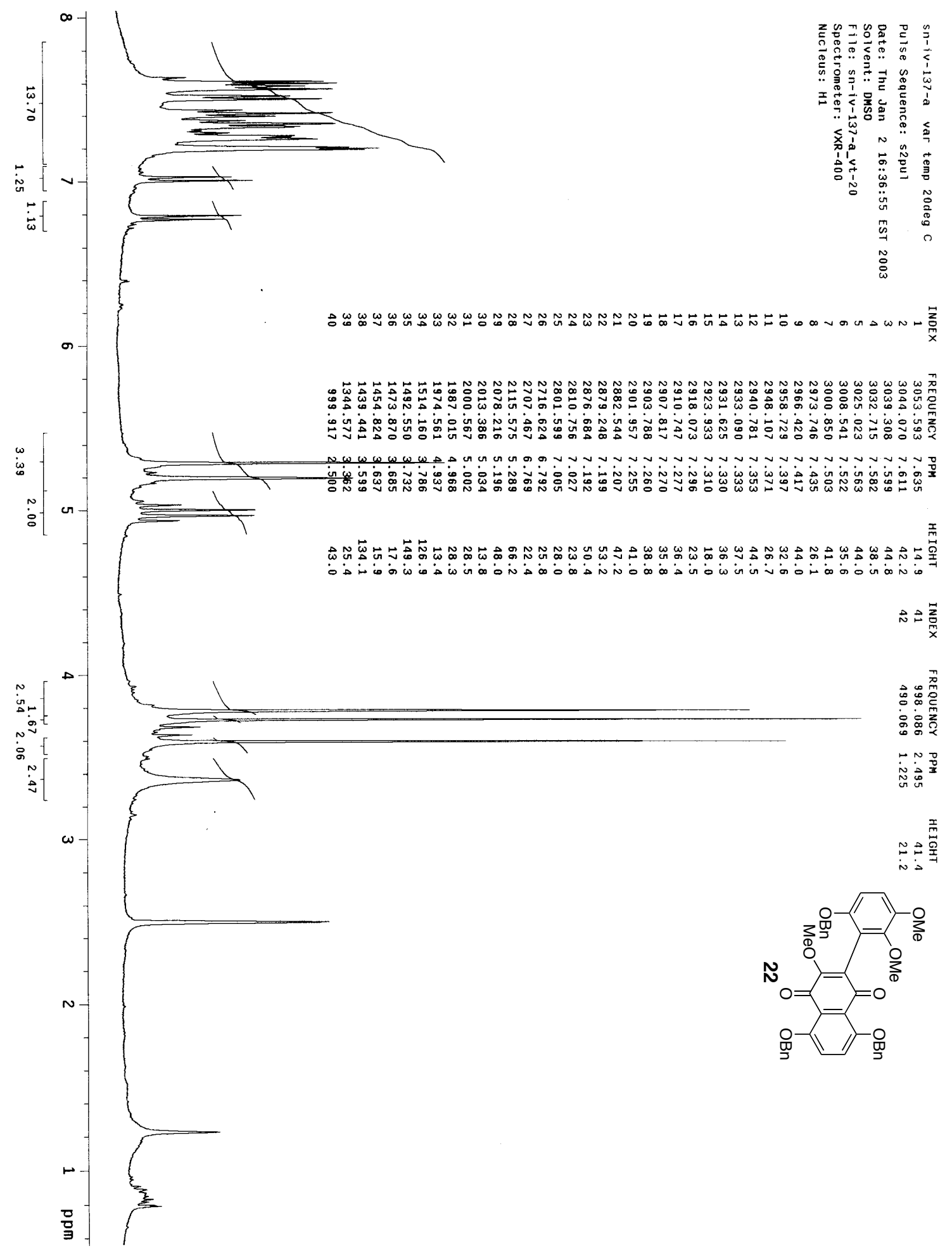




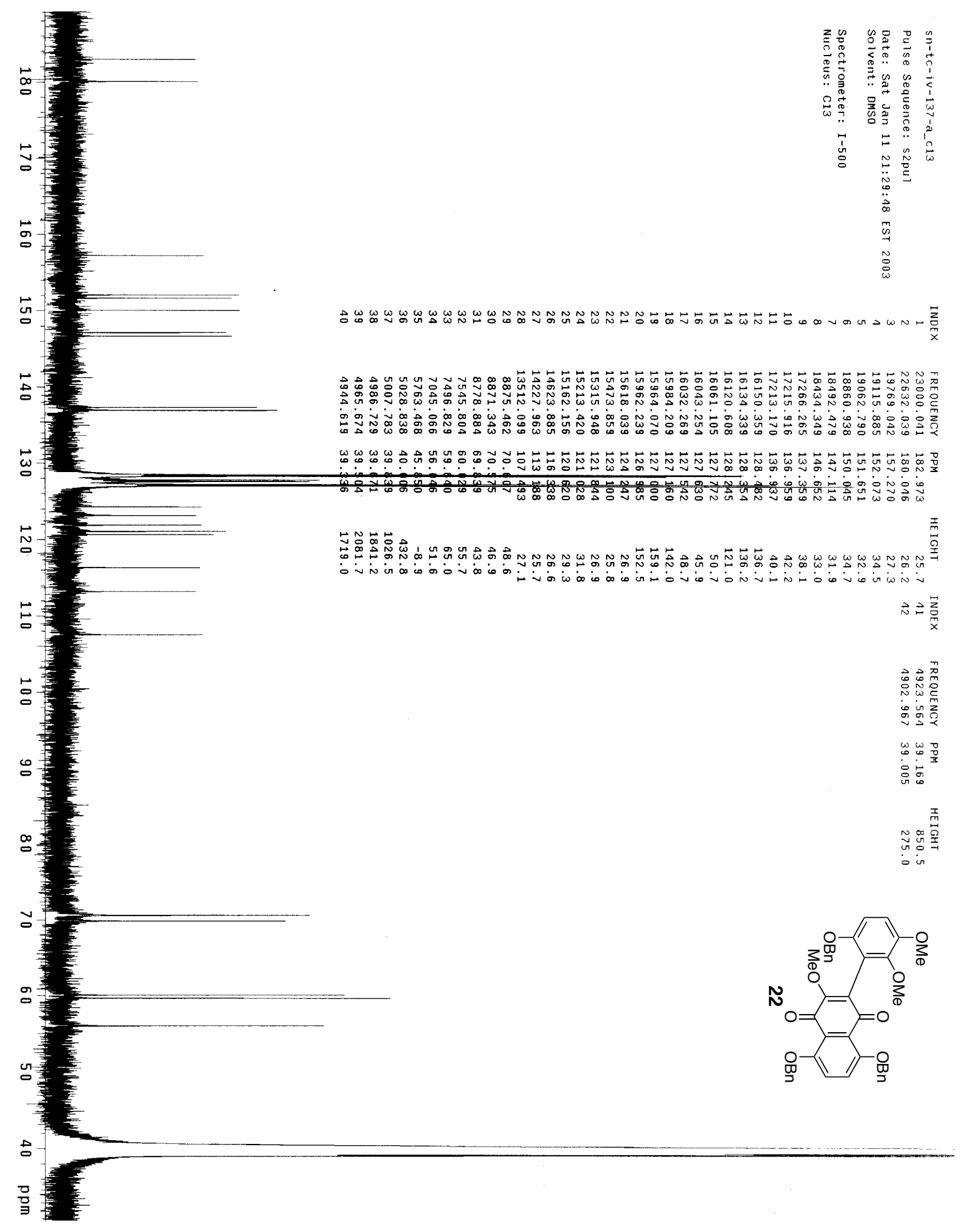

